\title{
Biodiversity ecosystem functioning research in freshwater phytoplankton: A comprehensive review of trait-based studies
}

\author{
Patrick Venail ${ }^{1,2}$ \\ ${ }^{1}$ Department F.-A. Forel for Environmental and Aquatic Sciences, University of Geneva; ${ }^{2}$ Institute for Environmental Sciences, ISE, \\ Geneva, Switzerland
}

\begin{abstract}
In an effort to reach a clearer mechanistic understanding of the influence of biological diversity on ecosystem functioning, research in the field is increasingly applying a trait-based approach. In this comprehensive review, I searched for and analyzed studies that focused on the relationship between biodiversity and ecosystem functioning (BEF) using a trait-based approach in freshwater phytoplankton from lentic systems (lakes, ponds, reservoirs). I found that this type of studies is very rare and included a plethora of traits, diversity metrics, statistical analyses and study locations that contributed to the high variability in the results they obtained. Overall, trait-based diversity is not a very good predictor of ecosystem functioning in freshwater lentic ecosystems. Null relationships between trait-based diversity and ecosystem functioning in freshwater lentic systems were the more frequent outcome. When significant, the amount of variation in ecosystem functioning explained by trait-based diversity was small. Still, trait-based research remains a promising approach to increase the mechanistic understanding of BEF relationships. For this purpose, studies directly testing the underlying mechanistic rationale, exploring diversity effects on the temporal stability of ecosystem functions, including multiple functions at a time, focusing more in cell size and shape and confirming the relative importance of individual trait variation for ecosystem functioning are needed.
\end{abstract}

Key words: Biodiversity; freshwater; functioning; phytoplankton; traits.

Received: November 2017. Accepted: December 2017.

\section{INTRODUCTION}

The field of biodiversity-ecosystem functioning (BEF) studies the impact that changes in biological diversity can have on the functioning of ecological systems. For instance, it depicts the consequences of biodiversity loss in terms of basic functions such as nutrient uptake, respiration, primary production and nutrient recycling, among others. In BEF research, diversity is quantified generally as the number of species (i.e., richness) or using other richness-based metrics that include species' abundances (e.g., Simpson index, Shannon index, Evenness). Overall, and despite some exceptions, it is well established that most ecosystem functions and their temporal stability increase as the number of species increases (Hooper et al., 2005; Cardinale et al., 2012; Duffy et al., 2017). Given the low explanatory power of such richness-based diversity metrics and the absence of a proper mechanistic elucidation, BEF research is increasingly adopting a trait-based perspective (Flynn et al., 2011; Cardinale et al., 2012; Krause et al., 2014; Gagic et al., 2015). Trait variability and the resulting ecological differentiation among species are considered as major determinants of the nature and strength of species interactions and consequently are expected to have a direct strong influence on ecosystem functioning. However, determining and quan- tifying the traits that are relevant for ecosystem functioning is not straightforward. Despite the importance of phytoplankton for global scale processes such as oxygen production and primary production, trait-based BEF studies with phytoplankton remain rare. Here, I review existing studies linking trait-based diversity to ecosystem functioning in freshwater lentic systems, summarize their major findings and provide some ideas for future development of this underexplored line of research.

\section{STUDY SELECTION}

I collated all the published empirical studies on the relationship between freshwater phytoplankton diversity in lentic systems (lakes, reservoirs, ponds) and any aspect of their functioning. I first collected all previous reviews and meta-analyses on the topic of biodiversity and ecosystem functioning (BEF), irrespective of the organism included and checked for references on freshwater phytoplankton (Hooper et al., 2005; Srivastava and Vellend, 2005; Balvanera et al., 2006; Cardinale et al., 2009; Cardinale et al., 2011; Cardinale et al., 2013; Gross et al., 2014; Duffy et al., 2017). This was supplemented with a search of the ISI Web of Science database using the keyword sequence combining (freshwater OR lake OR pond OR reservoir) AND (phytoplankton* OR alga* OR diatom 
OR cyano*) AND (trait* OR function*) AND (diversity OR richness) AND (community OR ecosystem) AND (function* OR product* OR biomass OR biovolume OR resource use). In this review, I only included studies that statistically analyzed the link between any trait-based metric of diversity and ecosystem functioning using freshwater phytoplankton. I excluded studies in lotic systems (i.e., rivers and streams) and studies in which phytoplanktonic organisms were classified into functional groups, such as major algal groups or Reynold's classification because they did not include a clear trait-based diversity measure (Schmidtke et al., 2010; Behl et al., 2011; Borics et al., 2012; Fernandez et al., 2014; Abonyi et al., 2017).

\section{STUDIES}

I found only six studies that explored the relationship between trait-based diversity and ecosystem functioning using freshwater phytoplankton from lentic systems (Tab. 1). These studies are recent, with the oldest published only seven years ago (Vogt et al., 2010), revealing that, on average, less than one study per year has been published in this topic. The six studies can be separated into two categories: field and laboratory studies. The former includes four studies in which both trait-based diversity and ecosystem functioning data were obtained from natural conditions (Vogt et al., 2010; Pälffy et al., 2013; Santos et al., 2014; Fontana et al., 2017). In the other two studies, diversity was directly manipulated under highly controlled conditions in the laboratory (Shurin et al., 2014; Steudel et al., 2016). The main conclusions of these studies regarding the link between trait-based diversity and functioning are quite variable (Tab. 1). Below, I explore those differences more in detail.

\section{ORGANISMS AND FRESHWATER SYSTEMS}

The six studies reported a wide variety of organisms from all major phytoplankton groups including mostly chlorophyta (green algae), chrysophyta (golden algae), bacillariophyta (diatoms) and cyanophyta (cyanobacteria). Phytoplankton from other major groups such as glaucophyta and heterokontophyta were less frequent. The richness of taxa within each study was rather variable. The laboratory studies included 16 (Shurin et al., 2014) and 64 (Steudel et al., 2016, only chlorophytes) taxa respectively, whereas field studies reported 212 (Vogt et al., 2010) and 412 species (Santos et al., 2014). The other two field studies did not report the number of species analyzed. Field data were collected in a variety of freshwater systems around the world: Vogt et al. (2010) included data from 65 lakes in Canada, Pälffy et al. (2013) from one single lake in Hungary, Santos et al. (2014) included 19 reservoirs from Brazil, whereas Fontana et al. (2017) reported data from 28 lakes in total, 2 from Switzerland and 26 from the Danube delta in Romania.

\section{TRAITS}

A total of 33 traits were included in the six studies about the effect of trait-based phytoplankton diversity on ecosystem functioning in freshwater lentic systems (Tab. 2). The authors selected such traits based on their supposed ecological relevance for competitive interactions, reproduction, predator avoidance, resource acquisition and/or bioenergy production. Most of these traits were measured at the species level, meaning that they represent an average value obtained by measuring and recording traits in some representative individuals or populations from each species. Different to all other studies, Fontana et al. (2017) recorded individual level data for seven traits, meaning that species' identification was not required prior to trait measurement and the reported trait values may reveal both intra and inter-specific variability in the phytoplankton community.

Traits reported belong to three different categories: demographic, morphological or physiological. Demographic

Tab. 1. List of trait-based BEF studies in freshwater lentic systems, type of study and their main conclusions regarding trait-based diversity effects on ecosystem functioning.

\begin{tabular}{|c|c|c|}
\hline Reference & Type of study & Main conclusion \\
\hline Vogt et al., 2010 & Field & Trait-based diversity was positively associated with total community biovolume \\
\hline Pälffy et al., 2013 & Field & $\begin{array}{l}\text { Significant negative correlations between total biomass, functional group diversity and functional } \\
\text { group evenness }\end{array}$ \\
\hline Santos et al., 2014 & Field & $\begin{array}{l}\text { A positive relation between productivity and diversity, except for functional evenness for which } \\
\text { the relation was negative }\end{array}$ \\
\hline Fontana et al., 2017 & Field & Trait evenness exhibited a robust negative relationship with biomass \\
\hline Shurin et al., 2014 & Laboratory & $\begin{array}{l}\text { Biomass yield exceeded the component monocultures in polycultures consisting of species with } \\
\text { highly divergent traits }\end{array}$ \\
\hline Steudel et al., 2016 & Laboratory & Functional diversity was positively correlated with biomass overyield \\
\hline
\end{tabular}

$\mathrm{BEF}$, biodiversity and ecosystem functioning. 
(7 traits), also named life history traits, are all continuous and include population growth parameters such as $r$ or $K$ (measured by using chlorophyll $a$ as a proxy for growth; Shurin et al., 2014). In another study, Vogt et al. (2010) included five demographic traits reported as "response traits" because they are based on how different environmental parameters influence population growth. These include: optimal growth conditions regarding total nitrogen, total phosphorous, $\mathrm{pH}$, dissolved organic carbon and dissolved $\mathrm{CO}_{2}$. Morphological (10 traits), include continuous, categorical or binomial traits. In this category, we find cell size, also reported in some studies as cell volume, greatest axial linear dimension (GALD), maximal linear dimension (MLD) or maximum length. This is the more frequently used trait, included in five different studies (Tab. 2). While cell size is normally reported as a contin- uous variable, Palffy et al. (2013) reported it as a categorical variable with three size classes. Other morphological traits that are reported in multiple independent studies are growth form (referring to either colonial or single cell organisms), presence of gas vacuoles (referring to buoyancy control capabilities), and the presence of flagella, that relates to motility. The other six traits in the morphological category were only reported in one independent study and can be either binomial or continuous (Tab. 2). Physiological (16 traits) represent the largest array of features among the three categories and can be either continuous, categorical or binomial and each was reported in only one study. These traits relate to minimum resource requirements (light, nitrogen, phosphorous, silica), cellular chemical content, biochemistry or stoichiometry (lipids, fatty acid, carbon, nitrogen, phosphorous), resource ac-

Tab. 2. List of traits included in BEF studies with freshwater phytoplankton.

\begin{tabular}{|c|c|c|c|}
\hline Demographic & ER & Type & Reference \\
\hline $\begin{array}{l}\text { Exponential growth rate, } r^{*} \\
\text { Asymptotic density, } K^{*} \\
\text { Total Nitrogen optimal concentration } \\
\text { Total Phosphorous optimal concentration } \\
\text { pH optimal } \\
\text { Dissolved Organic Carbon optimal } \\
\text { Dissolved CO2 optimal }\end{array}$ & $\begin{array}{l}\text { BP, CI } \\
\text { BP, CI }\end{array}$ & $\begin{array}{l}\text { Continous } \\
\text { Continous } \\
\text { Continous } \\
\text { Continous } \\
\text { Continous } \\
\text { Continous } \\
\text { Continous }\end{array}$ & $\begin{array}{l}\text { Shurin et al., } 2014 \\
\text { “" } \\
\text { “ } \\
\text { “ } \\
\text { “ } \\
\text { “ }\end{array}$ \\
\hline \multicolumn{4}{|l|}{ Morphological } \\
\hline $\begin{array}{l}\text { Cell volume/size/GALD/MLD/max length } \\
\text { Growth form/body form/complexity } \\
\text { Surface to volume ratio, } s / v \\
\text { Presence of aerotopes/gaz vacuoles/buoyancy } \\
\text { Presence of flagella/motility } \\
\text { Presence of mucilage } \\
\text { Presence of siliceous exoskeletal structures } \\
\text { Presence of heterocysts } \\
\text { Frontal shape of particle } \\
\text { Cell rugosity/internal structure/gas vesicle/thylacoids }\end{array}$ & $\begin{array}{l}\text { PA, RA, RE, BP, CI } \\
\text { PA, RA, RE } \\
\text { PA, RA } \\
\text { PA, RA } \\
\text { PA, RA } \\
\text { PA, RA } \\
\text { PA, RA } \\
\text { RA } \\
\text { PA, RA }\end{array}$ & $\begin{array}{l}\text { Continous/categorical } \\
\text { Categorical } \\
\text { Continous } \\
\text { Binomial/categorical } \\
\text { Binomial } \\
\text { Binomial } \\
\text { Binomial } \\
\text { Binomial } \\
\text { Continous } \\
\text { Continous }\end{array}$ & $\begin{array}{l}\text { all but Steudel et al., } 2016 \\
\text { Pälffy et al., 2013; Santos et al., } 2014 \\
\text { Pälffy et al., 2013 } \\
\text { Pälffy et al., 2013/Santos et al., } 2014 \\
\text { “ } \\
\text { Santos et al., } 2014 \\
\text { “ } \\
\text { “ } \\
\text { Fontana } \text { et al., 2017 }\end{array}$ \\
\hline \multicolumn{4}{|l|}{ Physiological } \\
\hline $\begin{array}{l}\text { Cellular lipid concentration } \\
\text { Cellular C:N ratio } \\
\text { Cellular C:P ratio } \\
\text { Minimum light requirement, } \mathrm{L}^{*} \\
\text { Minimum nitrogen requirement, } \mathrm{N}^{*} \\
\text { Minimum phosphorous requirement, } \mathrm{P}^{*} \\
\text { Fatty acid composition } \\
\text { Photosynthetic pigment composition } \\
\text { Fluorescence chlorophyl a } \\
\text { Fluorescence phycoerythrin } \\
\text { Fluorescence accesory pigments } \\
\text { Eveness in the distribution of pigments within cell } \\
\text { Hability to fix nitrogen } \\
\text { Phagotrophic potential } \\
\text { Motility/buoyancy } \\
\text { Presence of toxins }\end{array}$ & $\begin{array}{l}\text { BP, CI } \\
\text { BP, CI } \\
\text { BP, CI } \\
\text { BP, CI } \\
\text { BP, CI } \\
\text { BP, CI } \\
\text { CI }\end{array}$ & $\begin{array}{l}\text { Continous } \\
\text { Continous } \\
\text { Continous } \\
\text { Continous } \\
\text { Continous } \\
\text { Continous } \\
\text { Continous } \\
\text { Categorical } \\
\text { Continous } \\
\text { Continous } \\
\text { Continous } \\
\text { Continous } \\
\text { Binomial } \\
\text { Binomial } \\
\text { Categorical } \\
\text { Binomial }\end{array}$ & $\begin{array}{l}\text { Shurin et al., } 2014 \\
\text { “" } \\
\text { “" } \\
\text { “ } \\
\text { Steudel et al., } 2016 \\
\text { Pälffy et al., } 2013 \\
\text { Fontana et al., } 2017^{\circ} \\
\text { “ } \\
\text { “ } \\
\text { Pälffy et al., } 2013 \\
\text { “ } \\
\text { Santos et al., } 2014\end{array}$ \\
\hline
\end{tabular}

BEF, biodiversity and ecosystem functioning; ER, ecological relevance as explicitly claimed by the authors; RA, resource acquisition; RE, reproduction; PA, predator avoidance; BP, bioenergy production; CI, competitive interactions; * growth using fluorescence (chl a); ${ }^{\circ}$ individual level traits. 
quisition (pigments, phagotrophy, nitrogen fixation) and toxin production.

\section{TRAIT-BASED DIVERSITY VARIABLES AND METRICS}

The six studies reviewed here include 29 trait-based variables that were associated to ecosystem functioning afterwards (Tab. 3). These variables can be classified in three categories: functional group based variables, traitbased diversity metrics and trait-based non-diversity metrics. The functional group category includes well-known diversity metrics that are traditionally used to quantify species-level diversity such as richness, Shannon index, Simpson index and Evenness (the three latter incorporate information on species' abundances). For this, species are first classified into functional groups such as those proposed by Kruk (Kruk et al., 2010) or in major algae groups (e.g., chlorophytes or cyanophytes). Then, the different metrics were calculated based on group richness' information. Kruk's classification is based on morphological aspects and consequently corresponds to actual traitbased quantification of diversity; classifications based on major algae groups or Reynold's groups are not traitbased only (Reynolds et al., 2002) and as such should not be considered as formal traits-based diversity metrics. The other two categories of trait-based metrics require collecting trait information on species (but see Fontana et al., 2017 for individual level trait metrics). Species' traits are aggregated according to the taxa present in the natural community or artificial assemblage. This aggregation may include averaging, calculating distances or variation among species and other more sophisticated aggregation methods. The trait-based diversity metrics are the more common and diverse in the phytoplankton BEF literature, as I recorded up to 20 different metrics in five studies (Tab. 3). Some metrics incorporate information of one single trait (11 in total) at a time while others include up to six (Vogt et al., 2010), seven (Fontana et al., 2017), eight (Santos et al., 2014) or nine traits simultaneously (Shurin et al., 2014). This type of metrics can also be weighted by species' abundances. None of the twenty different diversity metrics based on traits were used in more than one study, revealing a large variability in the methodology of trait-based BEF studies. Up to six different metrics were used in one single study (Vogt et al., 2010).

Tab. 3. List of trait-based variables associated to ecosystem functioning in freshwater phytoplankton.

\begin{tabular}{|c|c|}
\hline Functional groups & Reference \\
\hline $\begin{array}{l}\text { Functional group richness (Kruk's groups, taxonomic) } \\
\text { Functional group diversity (Shannon } H f \text { ) } \\
\text { Functional group diversity (Evenness } J f \text { ) } \\
\text { Functional group diversity (Simpson) }\end{array}$ & $\begin{array}{l}\text { Santos et al., } 2014 \\
\text { Pälffy et al., } 2013 \\
\text { “ } \\
\text { Santos et al., } 2014\end{array}$ \\
\hline \multicolumn{2}{|l|}{ Trait-based diversity metric } \\
\hline $\begin{array}{l}\text { Difference in PCA vector (on } 9 \text { traits) } \\
\text { Functional dispersion, Fdis (on } 9 \text { traits) } \\
\text { Difference in C:N ratios between } 2 \text { species } \\
\text { Difference in cell volume between } 2 \text { species } \\
\text { Difference in minimun light requirement L* between } 2 \text { species } \\
\text { Fatty acid composition similarity, FTD } \\
\text { Fatty acid composition similarity, FD } \\
\text { Variance of species in total nitrogen optima, TV } \\
\text { Variance of species in total phosphorous optima, TV } \\
\text { Variance of species in pH optima, TV"Variance of species in dissolved organic carbon optima, TV } \\
\text { Variance of species in CO2 optima, TV" Sum branch length dendrogram (on } 6 \text { traits) } \\
\text { Functional richness based on distances, FR (on } 8 \text { traits) } \\
\text { Functional evenness based on distances, Feve (on } 8 \text { traits) } \\
\text { Functional divergence based on distances, } M F D \text { (on } 8 \text { traits) } \\
\text { Functional divergence weigthed by density, } M F D D e n s \text { (on } 8 \text { traits) } \\
\text { Trait diversity richness, TOP (on } 7 \text { traits) } \\
\text { Trait diversity evenness, TED (on } 7 \text { traits) } \\
\text { Trait diversity divergence, Fdis (on } 7 \text { traits) }\end{array}$ & $\begin{array}{l}\text { Shurin et al., } 2014 \\
\text { “ } \\
\text { “ } \\
\text { “ } \\
\text { Steudel et al., } 2016 \\
\text { “ } \\
\text { Vogt et al., } 2010 \\
\text { “ } \\
\text { “ } \\
\text { “ } \\
\text { Santos et al., } 2014 \\
\text { “ } \\
\text { “ } \\
\text { Fontana et al., } 2017 \\
\text { “ }\end{array}$ \\
\hline \multicolumn{2}{|l|}{ Other trait based gradients (not variation) } \\
\hline $\begin{array}{l}\text { Average PCA vector (on } 9 \text { traits) } \\
\text { Average cell volume of } 2 \text { species } \\
\text { Average C:P ratios of } 2 \text { species } \\
\text { Average C:N ratios of } 2 \text { species } \\
\text { Average minimum phosphorous requirement } P^{*} \text { of } 2 \text { species }\end{array}$ & $\begin{array}{l}\text { Shurin et al., } 2014 \\
\text { “ } \\
\text { “ } \\
\text { “ } \\
\text { “ }\end{array}$ \\
\hline
\end{tabular}


Finally, the third category includes trait-based metrics that do not represent diversity per se because they are just average traits among species and do not include information in the variation of a trait (Shurin et al., 2014). Some studies combine multiple of these metrics together in one single statistical analysis to determine the combinations of metrics describing better the variation in ecosystem functioning among communities (Santos et al., 2014; Fontana et al., 2017).

\section{ECOSYSTEM FUNCTIONING}

Five different variables were documented as measures of ecosystem functioning and can be separated in two categories: the biomass related and the non-biomass related. The two controlled laboratory studies (Shurin et al., 2014; Steudel et al., 2016) focused on biomass related ecosystem functioning variables. For this, they started by measuring the biomass of both polycultures and monocultures using optical density as a proxy. Then, two log-ratios were calculated: one between the biomass of the polyculture to the average of constitutive monocultures (i.e., Net Biodiversity Effect, NBE) and another between the biomass of the polyculture to the more productive monocultures (i.e., Overyielding, OY). This method can only be applied to controlled laboratory experiments because it requires monoculture's biomass estimations. The third biomass related variable, used in two field studies was total community biomass (Vogt et al., 2010; Fontana et al., 2017). The two nonbiomass related ecosystem functions included in the other field studies are chlorophyll $a$ concentration (Pälffy et al., 2013; Santos et al., 2014) and a proxy for resource use efficiency calculated as the ratio between total biomass and available total phosphorous (Fontana et al., 2017).

\section{BIODIVERSITY AND ECOSYSTEM FUNCTIONING RELATIONSHIPS}

A key step in every BEF study is to relate biodiversity (the explanatory variable) to ecosystem functioning (the response variable). In controlled laboratory studies, this link infers causality because all the observed variations in ecosystem functioning result from changes in either the diversity and/or the composition of the species assemblages being tested. In field studies, given the possibility of abiotic and biotic changes among sites or dates, the link between diversity and ecosystem functioning is just correlational. A plethora of statistical methods have been used to relate diversity to ecosystem functional as causality effects or correlational links, including correlations, linear regressions and linear mixed effect models. The latter allows combining multiple diversity metrics in one single statistical model (Steudel et al., 2016; Fontana et al., 2017). A total of 190 relationships between trait-based diversity and ecosystem functioning have been established so far for freshwater phytoplankton (Tab. 4). I classified them into either positive, null or negative based on the statistical analyses directly reported by the authors. Half of them showed no influence of trait-based diversity on ecosystem functioning, meaning that variations in functioning are independent from variations in trait diversity among freshwater phytoplankton. This higher prevalence of null relationships, compared to the significant ones, was consistent in both field and laboratory studies with $42 \%$ and $53 \%$ of total BEF relationships being null respectively. Positive BEF relationships, meaning that ecosystem functions considered increase as phytoplankton trait diversity increases, were present in nearly $40 \%$ of the experiments. The authors suggest some potential mechanisms to explain this positive effect of diversity. A larger functional trait-based diversity may embrace a wider range of optimal growth responses in face of changing abiotic lake conditions, leading to higher biomass production (Vogt et al., 2010). Also, species with different traits would be more complementary in resource use or compete less strongly against each other (Santos et al., 2014; Shurin et al., 2014). Negative relationships were present in $11.5 \%$ of cases, which means a decreasing ecosystem functioning as trait diversity increased. As an explanation for this pattern, authors suggest that under some condi-

Tab. 4. Summary table of the effect of trait-based metrics on ecosystem functioning.

\begin{tabular}{|c|c|c|c|c|}
\hline \multirow[t]{2}{*}{ Type of study } & \multirow[t]{2}{*}{ Reference } & \multicolumn{3}{|c|}{ Sign of trait based diversity effects on function } \\
\hline & & Positive & Null & Negative \\
\hline \multirow[t]{4}{*}{ Field } & Vogt et al., 2010 & 19 & 11 & 0 \\
\hline & Pälffy et al., 2013 & 0 & 0 & 4 \\
\hline & Santos et al., 2014 & 2 & 1 & 1 \\
\hline & Fontana et al., 2017 & 6 & 19 & 11 \\
\hline \multirow[t]{2}{*}{ Laboratory } & Shurin et al., 2014 & 8 & 2 & 6 \\
\hline & Steudel et al., 2016 & 40 & 60 & 0 \\
\hline Total & & 75 & 93 & 22 \\
\hline Percentage & & $39.5 \%$ & $49 \%$ & $11.5 \%$ \\
\hline
\end{tabular}


tions one single productive taxa with particular traits might dominate, leading to low functional diversity coupled to high biomass (Pälffy et al., 2013;Santos et al., 2014). Unfortunately, none of the studies reviewed here explicitly tested the suggested mechanisms and remained purely conjectural. Some authors also suggest that other forces (such as resource scarcity) might simultaneously influence both trait diversity and ecosystem functioning, resulting in a negative or positive pattern that is not mediated directly by diversity (Fontana et al., 2017).

\section{SOURCES OF VARIATION IN BEF RELATIONSHIPS}

The reviewed papers allowed determining a series of factors influencing the relationship between trait-based diversity and ecosystem functioning in experiments with freshwater phytoplankton. Vogt et al. (2010) found big differences in sign and strength of the BEF relationship depending on: the trait, the number of traits, the metric of diversity and the organisms included in the analysis. For instance, whereas functional diversity had a positive effect on total biovolume in the benthic algae, this effect was not present in the planktonic compartment. The inverse happened for functional diversity based on one single trait (i.e., $\mathrm{CO}_{2}$ optimal). Fontana et al. (2017) showed that the relationship between trait-based diversity and ecosystem functioning may also vary among locations. For instance, a combination of three trait-based diversity metrics describes very well variations in biomass in Lake Greifensee but this same set of metrics describes less well total biomass in Lake Zurich or the Danube delta. Steudel et al. (2016) showed that the effects of trait-based diversity also depend on the number of interacting species, with a tendency for higher influence of trait-based diversity as the number of species increases from two to sixteen.

\section{BEST TRAIT-BASED DESCRIPTORS OF ECOSYSTEM FUNCTIONING}

One purpose of BEF studies is to determine which trait (or set of traits) and which metric (or set of metrics) describes better variations in ecosystem functioning. In case of significant effects $(\mathrm{P}<0.05)$, either positive or negative, one wants to know which trait is the best predictor using coefficients of variance ( $\mathrm{R}^{2}$ values) and to compare models using for instance the Akaike information criterium (AIC). This would reveal which trait matters the most for ecosystem functioning in freshwater lentic ecosystems. One may as well want to know which traits do not influence ecosystem functioning. I collected data on the percentage of variation in ecosystem functioning explained by trait-based diversity and found that this percentage ranged from $1.8 \%$ to $90 \%$, with an average of $34.7 \%$ $(\mathrm{n}=51)$. The model that explained the most $(90 \%)$ of the variation in ecosystem functioning included one single metric of diversity (i.e., trait diversity evenness, TED), which was based on individual level trait variation and included seven different traits (Fontana et al., 2017). In studies focused on species level trait variation (5 out of 6 studies), the best single metric describing ecosystem functioning included information from six traits and explained $54 \%$ of variation in total biomass production in benthonic diatom communities (Vogt et al., 2010). The same study showed that the capacity to predict biomass production depended on the number of traits considered. This is, including two or three traits, rather than five or just one, increased the predictive power. This result suggests that different traits may incorporate different information but also that some traits might be functionally redundant and their use may not lead to a better description of biomass variation among communities.

\section{GENE-BASED DIVERSITY AS A PROXY FOR TRAIT-BASED DIVERSITY}

One study explored the capacity of gene-based diversity to predict freshwater phytoplankton functioning (Steudel et al., 2016). The underlying rationale is that gene differentiation among species (i.e., phylogenetic divergence) may relate to trait differentiation (assuming phylogenetic signal or phylogenetic niche conservatism; Blomberg and Garland 2002; Losos 2008; Wiens et al., 2010). Overall, the results show that the explanatory power is higher for trait-based diversity metrics than for gen-based diversity metrics. Moreover, at high richness level (16 species) both types of metrics have contrasting effects on biomass production. Trait-based metrics had a positive effect on biomass whereas gene-based metrics had a negative effect on biomass. This suggests that genebased metrics should not be considered as proxies of traitbased ones in freshwater communities.

\section{IDEAS FOR FUTURE DEVELOPMENT}

In the biodiversity-ecosystem functioning context, stability refers to the capacity of an ecological system to perform ecosystem functions despite variations (e.g., perturbations) in the abiotic or biotic conditions over time. Overall, diversity is expected to have a strong positive impact on ecosystem functioning stability given the capacity of a diverse set of organisms to cope with the different environmental conditions (Hooper et al., 2005; Tilman et al., 2006). Freshwater lentic ecosystems are steadily exposed to changing environmental conditions such as temperature, light intensity, resource input, etc. No study has 
explored the influence of trait-based diversity on the temporal stability of ecosystem functioning.

Trait-based BEF studies in freshwater phytoplankton focused on single functions. However, ecological systems often perform multiple functions at a time and some of these functions are expected to be directly related, such as resource uptake and biomass production. It has been suggested that diversity effects on ecosystem functioning might be stronger when multiple functions are considered simultaneously (Byrnes et al., 2014; Lefcheck et al., 2015). Such a multifunctional approach using trait-based diversity in freshwater lentic systems is missing.

Cell size and shape are considered as key traits for phytoplankton, directly influencing resource acquisition, reproduction, predator avoidance and species interactions (Litchman and Klausmeier, 2008; Finkel et al., 2010). Whereas some trait-based BEF studies reported here included phytoplankton cell size and/or shape in the estimation of trait-based diversity, only one study (Shurin et al., 2010) explored directly the effect of these traits on ecosystem functioning. More studies manipulating phytoplankton cell size and/or shape are required to provide more consistent conclusions on this topic.

Individual trait information may increase the descriptive power of ecosystem functioning (Fontana et al., 2017). More studies incorporating and comparing the explanatory capacity of individual vs. species trait-based metrics of diversity on ecosystem functioning are also required to determine the generality of this effect.

Finally, motivation to include trait-based information into BEF research supposes that trait variability among species reflects their ecological differentiation and thus determine the nature and strength of species interactions that ultimately influence ecosystem functioning. Trait-based studies reported to date did not explicitly test this rationale and the proposed mechanistic interpretations remain purely conjectural. Studies directly testing the underlying mechanisms such as the traits involved in the prevalence of competition or facilitation should be further developed.

\section{IN A NUTSHELL}

This first comprehensive review of studies linking traitbased freshwater phytoplankton in lentic systems to ecosystem functioning revealed the scarce research conducted in this topic, with only six published studies over the last seven years. Two of these studies were conducted under controlled laboratory conditions and the other four studies reported field collected data, in which other external variables might be influencing biodiversity-ecosystem functioning relationships. A total of 33 traits and 29 diversity metrics have been reported. Traits are either demographic, morphological or physiological. Some diversity metrics are based in one single trait but the majority include several traits simultaneously. No empirical evidence suggests that variation in one specific trait or group of traits improves the predictability of ecosystem functioning in freshwater lentic systems. Similarly, including multiple traits simultaneously or including multiple trait-based diversity metrics together does not necessarily make BEF relationships stronger. Nevertheless, a plethora of traits, diversity metrics, statistical analyses and study locations contributed to the high variability in the results obtained. Null relationship between trait-based diversity and ecosystem functioning in freshwater lentic systems was the more frequent outcome, accounting for nearly half of the experiments. When statistically significant, positive effects of trait-based diversity on ecosystem functioning were nearly four times more common than negative ones. In these studies, the amount of variation in ecosystem functioning explained by traitbased diversity was variable but rather small. Overall, this means trait-based diversity is often not a very good predictor of ecosystem functioning in freshwater lentic ecosystems. The capacity to improve our mechanistic understanding of biodiversity-ecosystem functioning relationships in freshwater lentic ecosystems using trait information has not been fully exploited. Studies directly testing the underlying mechanistic rationale are required. Other ideas for further development in this field include studying diversity effects on the temporal stability of ecosystem functions, exploring multiple functions at a time (multifunctionality), focusing exclusively in cell size and shape as master traits and confirming the relative importance of individual trait variation for ecosystem functioning.

\section{REFERENCES}

Abonyi A, Horváth Z, Ptacnik R, 2017. Functional richness outperforms taxonomic richness in predicting ecosystem functioning in natural phytoplankton communities. Freshwater Biol. Doi: 10.1111/fwb.13051. [Epub ahead of print].

Balvanera P, Pfisterer AB, Buchmann N, He JS, Nakashizuka T, Raffaelli D, Schmid B, 2006. Quantifying the evidence for biodiversity effects on ecosystem functioning and services. Ecol. Lett. 9:1146-1156.

Behl S, Donval A, Stibor H, 2011. The relative importance of species diversity and functional group diversity on carbon uptake in phytoplankton communities. Limnol. Oceanogr. 56:683-694.

Blomberg SP, Garland JrT, 2002. Tempo and mode in evolution: phylogenetic inertia, adaptation and comparative methods. J. Evol. Biol. 15:899-910.

Borics G, Tóthmérész B, Lukács BA, Várbíró G, 2012. Functional groups of phytoplankton shaping diversity of shallow lake ecosystems. Hydrobiologia 698:251-262.

Byrnes JEK, Gamfeldt L, Isbell F, Lefcheck JS, Griffin JN, Hector A, Cardinale BJ, Hooper DU, Dee LE, Duffy E, 2014. Investigating the relationship between biodiversity and ecosystem multifunctionality: challenges and solutions. Methods Ecol. Evol. 5:111-124. 
Cardinale BJ, Duffy JE, Gonzalez A, Hooper DU, Perrings C, Venail P, Narwani A, Mace GM, Tilman D, Wardle DA, Kinzig AP, Daily GC, Loreau M, Grace JB, Larigauderie A, Srivastava DS, Naeem S, 2012. Biodiversity loss and its impact on humanity. Nature 486:59-67.

Cardinale BJ, Gross K, Fritschie K, Flombaum P, Fox JW, Rixen C, van Ruijven J, Reich PB, Scherer-Lorenzen M, Wilsey BJ, 2013. Biodiversity simultaneously enhances the production and stability of community biomass, but the effects are independent. Ecology 94:1697-1707.

Cardinale BJ, Matulich KL, Hooper DU, Byrnes JE, Duffy E, Gamfeldt L, Balvanera P, O'Connor MI, Gonzalez A, 2011. The functional role of producer diversity in ecosystems. Am. J. Botany 98:572-592.

Cardinale BJ, Srivastava DS, Duffy JE, Wright JP, Downing AL, Samkaran M, Jouseau C, Cadotte MW, Carroll IT, Weis JJ, Hector A, Loreau M, 2009. Effects of biodiversity on the functioning of ecosystems. A summary of 164 experimental manipulations of species richness. Ecology 90:854.

Duffy JE, Godwin CM, Cardinale BJ, 2017. Biodiversity effects in the wild are common and as strong as key drivers of productivity. Nature 549:261-264.

Fernandez C, Cáceres EJ, Parodi ER, 2014. Phytoplankton development in a highly eutrophic man-made lake from the Pampa plain of Argentica - a functional approach. Int. J. Environ. Res. 8:1-14.

Finkel ZV, Beardall J, Flynn KJ, Quigg A, Rees TAV, Raven JA, 2010. Phytoplankton in a changing world: cell size and elemental stoichiometry. J. Plankt. Res. 32:119-137.

Fontana S, Thomas MK, Moldoveanu M, Spaak P, Pomati F, 2017. Individual-level trait diversity predicts phytoplankton community properties better than species richness or evenness. ISME J. Doi: 10.1038/ismej.2017.160. [Epub ahead of print]

Flynn DFB, Mirotchnick N, Jain M, Palmer MI, Naeem S, 2011. Functional and phylogenetic diversity as predictors of biodiversity ecosystem-function relationships. Ecology 92: 1573-1581.

Gagic V, Bartomeus I, Jonssin T, Taylor A, Winqvist C, Fischer C, Slade EM, Steffan-Dewenter I, Emmerson M, Potts SG, Tscharntke T, Weisser W, Bommarco R, 2015. Functional identity and diversity of animals predict ecosystem functioning better than species-based indices. Proc. R. Soc. B 282: 20142620.

Gross K, Cardinale BJ, Fox JW, Gonzalez A, Loreau M, Polley HW, Reich PB, van Ruijven J, 2014. Species richness and the temporal stability of biomass production: a new analysis of recent biodiversity experiments. Am. Nat. 183:1-12.

Hooper DU, Chapin FS, Ewel JJ, Hector A, Inchausti P, Lavorel S, Lawton JH, Lodge DM, Loreau M, Naeem S, Schmid B, SetalaH, Symstad AJ, Vandermeer, Wardle DA, 2005 Effects of biodiversity on ecosystem functioning: a consensus of current knowledge. Ecol. Monog. 75:3-35.

Krause S, Le Roux X, Niklaus PA, Van Bodegom PM, Lennon
JT, Bertilsson S, Grossart H-P, Philippot L, Bodelier PL, 2014. Trait-based approaches for understanding microbial biodiversity and ecosystem functioning. Front. Microbiol. 5:251.

Kruk C, Huszar VLM, Peeters ETHM, Bonilla S, Costa L, Lürling M, Reynolds C, Scheffer M, 2010. A morphological classification capturing functional variation in phytoplankton. Freshwater Biol. 55:614-627.

Lefcheck JS, Byrnes JEK, Isbell F, Gamfeldt L, Griffin JN, Eisenhauer N, Hensel MJS, Hector A, Cardinale BJ, Duffy E, 2015. Biodiversity enhances ecosystem multifunctionality across trophic levels and habitats. Nature Comm. 6:6936.

Litchman E, Klausmeier CA, 2008. Trait-based community ecology of phytoplankton. Annu. Rev. Ecol. Evol. Syst. 39:615-639.

Losos JB, 2008. Phylogeneitc niche conservatism, phylogenetic signal and the relationship between phylogenetic relatedness and ecological similarity among species. Ecol. Lett. 11:9951007.

Pälffy K, Présing M, Vörös L, 2013. Diversity patterns of traitbased phytoplankton functional groups in two basins of a large, shallow lake (Lake Balaton, Hungary) with different trophic state. Aquat. Ecol. 47:195-210.

Reynolds CS, Huszar V, Kruk C, Naselli-Flores L, Melo S, 2002. Towards a functional classification of the freshwater phytoplankton. J. Plankt. Res. 24:417-428.

Santos AMC, Carneiro FM, Cianciaruso MV, 2014. Predicting productivity in tropical reservoirs: the roles of phytoplankton taxonomic and functional diversity. Ecol. Ind. 48:428-435.

Schmidtke A, Gaedke U, Weithoff G, 2010. A mechanistic basis for underyielding in phytoplankton communities. Ecology 91:212-221.

Shurin JB, Mandal S, Abbott RL, 2014. Trait diversity enhances yield in algal biofuel assemblages. J. Appl. Ecol. 51:603-611.

Srivastava DS, Vellend M, 2005. Biodiversity-ecosystem function research: is it relevant to conservation. Annu. Rev. Ecol. Evol. Syst. 36:267-294.

Steudel B, Hallmann C, Loremz M, Abrahamczyk S, Prink K, Herrfurth C, Feussner I, Martini JWR, Kessler M, 2016. Contrasting biodiversity-ecosystem functioning relationships in phylogenetic and functional diversity. New Phytologist 212:409-420.

Tilman D, Reich PB, Knops JM, 2006. Biodiversity and ecosystem stability in a decade-long grassland experiment. Nature 441:629-632.

Vogt RJ, Beisner BE, Prairie YT, 2010. Functional diversity is positively associated with biomass for lake diatoms. Freshwater Biol. 55:1636-1646.

Wiens JJ, Ackerly DD, Allenn AP, Anacker BL, Buckley LB, Cornell HV, Damschen EI, Davies TJ, Grytnes J-A, Harrison SP, Hawkins BA, Holt RD, McCain CM, Stephens PR, 2010. Niche conservatism as an emerging principle in ecology and conservation biology. Ecol. Lett. 13:1310-1324. 